\title{
LETTSOM, HIS LIFE, TIMES, FRIENDS AND DESCENDANTS
}

\author{
By Dr. James Johnston Abraham.
}

Published by Wm. Heinemann (Medical Books) Ltd. Price 30/- net.

It is fortunate, we think, that Dr. Johnston Abraham chose as the title of his work "Lettsom, his life, times, friends and descendants," for in this way he was allowed the greatest latitude of which he has taken full advantage. The result is one of the best pictures of medical life of any period it has been our lot to come across. One cannot help but feel that it must have been a fine era to live in. The medicals at any rate were earnest in their work and appreciated what social life meant. There was ample friendship, as the numerous societies and clubs testify. There was, however, also much stimulating and enlivening controversy, so much so indeed that one is almost inclined to wish the habit of publishing pamphlets were resuscitated and took the place of the somewhat barren "letters to the editor" columns of today.

Dr. Abraham tells the story to a great extent by weaving together extracts from the letters and publications of the times, so that the whole has not only a particular freshness but also an undoubted authenticity. Lettsom himself must have been a fine type of man and a most valuable citizen of the City of London, so great was his share in all the serious developments of the time, and we do not wonder at the author's decision to perpetuate his memory. He, i.e., Lettsom, however, is only one of a galaxy of medical giants who move through the pages of this book and make one proud of his profession. If we have any regrets it is that we miss among the many portraits those of the famous brothers William and John Hunter, who we feel certain must have appreciated Lettsom as a man after their own heart.

So much have we enjoyed the book, and so vivid are the pen portraits, that we feel certain that the hope expressed by Dr. Johnston Abraham in his preface that "Lettsom may have become so real" that his readers "may meet him at any time" will" not infrequently be fulfilled.

\section{Miscellaneous.}

The Blue Funnel Line (Messrs. Alfred Holt \& Co.) have published "The DiaRy OF The Blue A 'Ulysses ' Passenger.' Without any form of restricFunnel Line. tion by the shipping company, an anonymous passenger has set out in detail his frank impressions of a fourmonths' voyage in the "Ulysses."

There is no laudatory preamble. The Diary opens : "Left home at 9.45 a.m. with Mildred and luggage. Arrived Liverpool 11.15. Had Turkish bath to alleviate lumbago. The masseur gave me hell, but did me good . . . ." The traveller records the trifling events of the first few days, then the trip through the Mediter- ranean until, in the Red Sea, his remarks bring home to us something of the comforts of modern travel. "This first experience of real heat makes one marvel at the endurance of our pioneer ancestors on their voyages of discovery in the tropics. Fancy being becalmed on a sailing vessel-no fans - no iced water-no bath-no grape-fruitno anything in the way of luxury. Then water running short-and no green vegetables, with consequent scurvy and other loathsome diseases-they must have had grit-those chaps !"

"I never enjoyed such a bathe before" -this was at Penang, in the Straits Settlements. Long drinks at Johore are described 